\title{
Expression of a barley cystatin gene in maize enhances resistance against phytophagous mites by altering their cysteine-proteases
}

\author{
Laura Carrillo • Manuel Martinez • \\ Koreen Ramessar · Inés Cambra · Pedro Castañera · \\ Felix Ortego $\cdot$ Isabel Díaz
}

\begin{abstract}
Phylocystatins are inhibitors of cysteine-proteases from plants putatively involved in plant defence based on their capability of inhibit heterologous enzymes. We have previously characterised the whole cystatin gene family members from barley (HvCPI-1 to HvCPI-13). The aim of this study was to assess the effects of barley cystatins on two phytophagous spider mites, Tetranychus urticae and Brevipalpus chilensis. The determination of proteolytic activity profile in both mite species showed the presence of the cysteine-proteases, putative targets of cystatins, among other enzymatic activities. All barley cystatins, except HvCPI- 1 and HvCPI-7, inhibited in vitro mite cathepsin L- and/or cathepsin B-like activities, HvCPI-6 being the strongest inhibitor for both mite species. Transgenic maize plants expressing HvCPI-6 protein were generated and the functional integrity of the cystatin transgene was confirmed by in vitro inhibilory effect observed against $T$. urticae and $B$. chilensis protein extracts. Feeding experiments impaired on transgenic lines performed with $T$. urticae impaired mite development and
\end{abstract}

reproductive performance. Besides, a significant reduction of cathepsin L-like and/or cathepsin B-like activities was observed when the spider mite fed on maize plants expressing HvCPI-6 cystatin. These findings reveal the potential of barley cystatins as acaricide proteins to protect plants against two important mite pests.

Keywords Cysteine protease $\cdot$ Phytocystatin $\cdot$ Spider mite Transgenic maize $\cdot$ Tetranychus urticae

Brevipalpus chilensis

\section{Introduction}

Crop losses due to herbivorous pest, mainly insects and mites, are estimated to be about $8-15 \%$ of the total yield for major crops worldwide, despite pesticide use (Oerke 2006). Phylophagous miles are members of the Acari subclass that feed by puncturing the plant parenchyma cells and sucking out their content. Particularly, Tetranychidae species have highly increased in Europe in the past years producing severe plant damages (Carbonelle et al. 2007). One of the major mite pests on agricultural crops is the two-spotted spider mite Tetranychus urticae Koch (Acari: Tetranychidae), a polyphagous species that has been recorded from over 150 plants of economic interest. It represents a key pest for greenhouse crops and ornamentals, annual field crops and perennial cultures all over the world (Jeppson et al. 1975). Other mites with an increasingly important economic impact are specific to certain latitude localizations such as the grape false spider mite Brevipalpus chilensis Baker (Acari: Tenuipalpidae), considered a Chilean native species that feed over 100 plants. This mile species is particularly important in red wine grapes where they can reduce yields over $30 \%$ (Fuentealba 
2003). Because of their short generation time and high population growth rates, mites have developed resistance to the major pesticide groups (Croft and Van de Baan 1988). In addition. no resistant plant cultivars are currently available, and phytophagous mites are not sensitive to toxins encoded by Bt genes (Rovenska et al. 2005: Obrist et al. 2006: Alvarez-Alfageme et al. 2008; $\mathrm{Li}$ and Romeis 2010).

Generate plants expressing transgenes targeted to silence or inhibit essential mite-specific genes could be one of these alternatives to combat them and to be included in conventional plant-assessment programmes. For this purpose. it is crucial to identify mite targets and define the processes or pathways that can be altered or inhibited. Genetically engineered plants expressing putative anti-mite genes have been generated as plant protection strategy. McCafferty et al. (2006) reported a significant reduction in the multiplication of carmine spider mite (Tetranychus cinnabarinus) reared on papayas expressing a chitinase gene. The transgenic papayas showed an increased tolerance both under laboratory conditions and field trials where natural mite infestation occurred. Similarly, an improved resistance to $T$. cinnabarinus was observed in papaya leaves transformed with the snowdrop GNA lectin gene (McCafferty et al. 2008). In contrast, tomato plants expressing the Gox (glucose oxidase) or $K T I 3$ (soybean Kunitz inhibitor) genes enhanced the T. urticae population growth under greenhouse conditions (Castagnoli et al. 2003).

Another putative target process is mite digestive physiology. Mites use both extracellular and intracellular digestion. with the latter occurring in free-floating gut wallderived epithelial cells that ingest and digest food particles. The midgut is the site for synthesis and secretion of digestive enzymes and absorption of nutrients, Processed food and cells pass into the posterior midgut, subsequently compacted in the hindgut and excreted as faecal pellets (Hamilton et al. 2003). Mite species that feed on plants rely mostly on cysteine peptidase activities for the digestion of dietary proteins (Nisbet and Billingsley 2000). Particularly. protease activity in extracts from $T$. urticae was almost totally explained by cysteine type protease activity in vitro assays and in zymograms (Michaud et al. 1996). Therefore, a control strategy based on the use of phytocystatins (PhyCys) would provide new tools to protect crops against spider mites.

PhyCys are plant proteinaceous inhibitors of cysteineproteases of the papain ClA family integrated into an independent subfamily on the cystatin phylogenetic tree (Margis et al. 1998; Martinez and Diaz 2008). The cystatin inhibitory mechanism is produced by a tight and reversible interaction with their target enzymes. It involves a tripartite wedge formed by the partially flexible $\mathrm{N}$-terminus containing a glycine residue and two hairpin loops carrying a conserved QxVxG motif and a tryptophan residue, respectively (Stubbs et al. 1990). In addition to these three motifs common to all cystatins, PhyCys contain a particular consensus sequence ([LVI]-[AGT]-[RKE]-[FY]-[AS]-[VI]$\mathrm{x}$-[EDQV]-[HYFQ]-N) conforming a predicted secondary $\alpha$-helix structure (Margis et al. 1998). Most PhyCys are small proteins with a molecular mass in the $12-16 \mathrm{kDa}$ range, but there are some with a molecular weight of $23 \mathrm{kDa}$. These PhyCys have a carboxy-terminal extension which is involved in the inhibition of a second family of cysteine-proteases, the $\mathrm{C} 13$ legumain peptidases (Martinez et al. 2007; Martinez and Diaz 2008). Several 85-87 kDa multicystatins, with eight cystatin domains, have also been described (Girard et al. 2007: Nissen et al. 2009). From a finctional viewpoint, PhyCys have been implicated in regulation of the protein turn-over and as defense proteins. The defense role has been inferred from the ability of PhyCys to inhibit digestive proteases from herbivorous arthropods in vitro, as well as by bioassays in artificial diets and on transgenic plants over-expressing PhyCys genes (Pernas et al. 1998; Alvarez-Alfageme et al. 2007; Carrillo et al. 2010). Deleterious effects against phytopathogenic fingi and viruses have also been described for these inhibitors (Gutierrez-Campos et al. 1999: Martinez et al. 2003; Abraham et al. 2006). To the best of our knowledge. there is only a reference showing the acaricide properties of a phytocystatin. the $\mathrm{CsC}$ cystatin from chestnut (Pernas et al. 2000). The $\mathrm{CsC}$ inhibited the crude digestive protease activity of the house dust mite Dermatophagoides farinae and drastically increased the mite larval mortality when was added to a semisynthetic diet.

The aim of this study was to determine the potential acaricide properties of barley cystatins against phytophagous mites. We analysed the in vitro inhibitory effects and specificity of whole gene family members of barley cystatins (HvCPI-1 to HvCPI-13, Martinez et al. 2009) on two spider mites. $T$. urticae and $B$. chilensis, that rely on cysteine-proteases for digestion. Transgenic maize plants expressing the cystatin HvCPI-6 were prepared and their effects on $T$. urticae were analysed. Moreover, we have characterized further the protease activity profiles of protein extracts from these two mite species to determine the proteolytic alterations after feeding on transgenic plants.

\section{Materials and methods}

Purification of recombinant cystatins and inhibitory activity against mite extracts

The cDNA fragments spanning the whole cystatin ORFs, aside from their signal peptide sequences, were inserted in 
frame into the expression vector pRSETB (Invitrogen). The recombinant plasmids for barley HvCPI-1 to HvCPI-13 cystatins were produced and introduced in Escherichia coli as described in Martinez et al. (2009). The fusion proteins with a His6 tag were purified using a His-Bind Resin (Novagen) following the manufacturer's instructions, and purification checked by SDS-PAGE.

A $T$. urticae colony was reared on maize plants in environmental chambers at $25^{\circ} \mathrm{C}, 70 \%$ relative humidity and a $16 \mathrm{~h} / 8 \mathrm{~h}$ day/night photoperiod. Mites were collected and stored frozen $\left(-20^{\circ} \mathrm{C}\right)$ until needed. Lyophilized samples of $B$. chilensis were provided by Dr. Marina Gambardella (Pontificia Universidad Católica de Chile, Chile). Mites from both species were homogenized in $0.15 \mathrm{M} \mathrm{NaCl}(600 \mathrm{mg} / \mathrm{ml})$, centrifuged at $10,000 \mathrm{~g}$ for $5 \mathrm{~min}$ and the supernatants pooled to obtain soluble protein extracts for enzymatic activity assays.

For inhibitory enzymatic activity assays, hydrolysis of substrates containing the AMC (7-amino-4-methyl coumarin) fluorophore was carried out in microlitre plate format. The standard assay volume was $100 \mu \mathrm{l}$, using a buffer containing $100 \mathrm{mM}$ sodium phosphate $\mathrm{pH} 6.0$. $10 \mathrm{mM}$ L-cysteine, $10 \mathrm{mM}$ EDTA, and $0.01 \%$ (v/v) Brij35 and $0.5 \mu \mathrm{g}$ and $1.0 \mu \mathrm{g}$ of soluble protein extracted from $T$. urticae and $B$. chilensis, respectively. The cystatins, at a final concentration of $0.4 \mu \mathrm{g}$ were incubated at $30^{\circ} \mathrm{C}$ with the protein extracts for $10 \mathrm{~min}$. prior to adding the substrate at a final concentration of $0.2 \mathrm{mM}$. Cathepsin B- and L-like activities were assayed using Z-RR-AMC ( $N$-carbobenzoxyloxy-Arg-Arg-7-amido-4-methylcoumarin) and Z-FR-AMC ( $N$-carbobenzoxyloxy-Phe-Arg-7-amido-4-methylcoumarin) substrates, respectively. The reaction was incubated at $30^{\circ} \mathrm{C}$ and emitted fluorescence measured with a $365-\mathrm{nm}$ excitation wavelength filter and a 465-nm emission wavelength filter. The system was calibrated with known amounts of AMC hydrolysis product in a standard reaction mixture. Results were expressed as a percentage of protease activity relative to that in the absence of the inhibitor. All assays were carried out in triplicate and blanks were used to account for spontaneous breakdown of substrates.

\section{Gelatin-PAGE gels}

Electrophoretic detection of proteolytic forms of mite extracts was performed using $0.1 \%(\mathrm{w} / \mathrm{v})$ gelatin-containing $0.1 \%$ (w/v) SDS $12 \%$ (w/v) polyacrylamide slabs gels according to Lantz and Ciborowski (1994). The acrylamide to bis-acrylamide ratio was $37.5: 1$. Protein extracts from mites ( $3 \mu \mathrm{g}$ of total protein) were diluted into two-fold in electrophoresis sample buffer containing $62.5 \mathrm{mM}$ Tris$\mathrm{HCl} \mathrm{pH} 6.8 .2 \%(\mathrm{w} / \mathrm{v})$ SDS. $10 \%$ (w/v) glycerol. $0.05 \%(\mathrm{w} /$ v) bromophenol blue and subjected to electrophoresis using a Bio-Rad Mini-Protein II Electrophoresis Cell System.
After migration at $4^{\circ} \mathrm{C}$, gels were transferred into a $2.5 \%$ (v/v) aqueous solution of Triton X-100 for $30 \mathrm{~min}$ at room temperature, to allow restoration of the proteases. Gels were then placed in an activation buffer $(0.1 \mathrm{M}$ phosphate pH 6.0 with $10 \mathrm{mM}$ cysteine) for $20 \mathrm{~h}$ at $30^{\circ} \mathrm{C}$. Proteolysis was stopped by transferring the gels into a staining solution $0.3 \%(\mathrm{w} / \mathrm{v})$ Coomassie Blue R-250 in $40 \%$ (v/v) methanol and $10 \%(\mathrm{v} / \mathrm{v})$ acetic acid. The gels were distained in $25 \%$ $(\mathrm{v} / \mathrm{v})$ methanol and $10 \%(\mathrm{v} / \mathrm{v})$ acetic acid.

\section{Enzyme activity assays}

A series of overlapping buffers were used to generate a pH range from 2.0 to 11.0 . Reaction buffers for the characterization of mite proteases were $0.1 \mathrm{M}$ citric acid $\mathrm{NaOH}$ (pH 2.0-3.0), 0.1 M citrate (pH 3.0-6.0), 0.1 M phosphate (pH 6.0-7.0), 0.1 M Tris-HCl (pH 7-9.5) and $0.1 \mathrm{M}$ glycine-NaOH $(\mathrm{pH}$ 9.5-11.0). All buffers contained $0.15 \mathrm{M} \mathrm{NaCl}$ and $5 \mathrm{mM} \mathrm{MgCl}_{2}$.

Hydrolysis of substrates containing the AMC fluorophore was carried out as described earlier. The standard assay contained $0.5-2.0 \mu \mathrm{g}$ of protein extract prepared from the two mites and the corresponding substrate added to a final concentration of $0.2 \mathrm{mM}$. Cathepsin B-like and L-like activities were assayed as described earlier. Trypsin-like activity was assayed using ZLA-AMC (Z-L-arginine-7-amido-4-methyl coumarin), chymotrypsin-like activity using SAAPP-AMC (Suc-Ala-Ala-Pro-Phe-7-amido-4-methyl coumarin), elastase-like activity using MeOSAAPV-AMC (MeOSucAla-Ala-Pro-Val-7-amido-4-methyl coumarin) and leucine aminopeptidase-like activiry using LL-AMC (L-leucine 7-amido-4-methyl coumarin). The reaction was incubated at $30^{\circ} \mathrm{C}$ and the fluorescence emission was measured as indicated earlier.

Cathepsin D-like activity was assayed in $0.5 \mathrm{ml}$ of reaction buffer containing $10 \mu \mathrm{g}$ of mite extract, using $0.2 \%$ haemoglobin as described by Novillo et al. (1997). Carboxypeptidases $\mathrm{A}$ and $\mathrm{B}$-like activities were assayed in $0.5 \mathrm{ml}$ of reaction buffer containing $20 \mu \mathrm{g}$ of mite extracts, using $1 \mathrm{mM}$ HPA (hippuryl-phenylalanine) for carboxypeptidase A-like activities and $1 \mathrm{mM}$ HA (hippurylL-arginine) for carboxypeptidase B-like activities as described by Ortego et al. (1996).

The proteolytic activities of $T$. urticae and $B$. chilensis extracts were assayed for characterization purposes in the presence of the following class-specific diagnostic inhibitors: the cysteine protease inhibitor. E-64 (L-trans-epoxysuccinyl-leucylamido-(4-guanidino)-butano); the serine protease inhibitor. STI (soybean trypsin inhibitor); the aspartyl protease inhibitor, Pep-A (pepstatin-A); the carboxypeptidase inhibitor, PCPI (potato tuber carboxypeptidase inhibitor); and the heavy metal $\mathrm{CdCl}_{2}$ as inhibitor of aminopeptidases and some other metalloproteases (Salvesen 
and Nagase, 1989). Protease inhibitors were incubated at $30^{\circ} \mathrm{C}$ for $15 \mathrm{~min}$ with the extracts prior to adding the substrate. All compounds were added to a final concentration of $0.2 \mu \mathrm{M}$, except PCPI that was added to a final concentration of $0.02 \mu \mathrm{M}$.

Total protein content was determined according to the method of Bradford (1976) with bovine serum albumin (BSA) as a standard. All assays were carried out in triplicate and blanks were used to account for spontaneous breakdown of substrates.

Plasmid constructs and plant transformation

The pUC-lcy6 plasmid used in the maize transformation is a vector derived from the pUC19 containing entire coding region of the barley cystatin Icy6 gene under the control of the maize ubiquitine promoter plus its first intron, followed at the $3^{\prime}$ end by the nopaline synthase gene (NOS) $3^{\prime}$-terminator (Fig. 2a). As selectable marker was used the bar gene included in the pAHC25 plasmid, which also contained the reporter uidA gene encoding the $\beta$-glucuronidase (Christensen and Quail 1996).

Immature zygotic embryos of the South African elite white maize $\mathrm{M} 37 \mathrm{~W}$ inbred were transformed by particle bombardment according to Ramessar et al. (2008). Bombarded embryos were incubated on N6-based medium under dark for 15 days and then transferred every 2 weeks to fresh N6-based medium containing $3 \mathrm{mg} / 1$ phosphinothricin (PPT). Four to six weeks after bombardment, pieces of PPT-resistant embryogenic type I callus were cultured on regeneration medium plus $3 \mathrm{mg} / 1 \mathrm{PPT}$ for $2-4$ weeks with a $16 \mathrm{~h} / 8 \mathrm{~h}$ day/night photoperiod. Development plantlets with well-formed shoots and roots were hardened off in soil. Independent events were pollinated with nontransformed white maize $M 37 \mathrm{~W}$ pollen to produce $T_{1}$ seeds and plants containing the barley Icy6 gene were used for further analysis.

Nucleic acid analysis

Total DNA was isolated from transformed and control maize leaves essentially as described by Taylor and Powell (1982) and tested for the presence of the cystatin gene by PCR. Specific primer pair derived from the $I c y 6$ gene was used: forward: $5^{\prime}$-CGAGGTACCATGGCCACCTCGGCC CTCGGC- $3^{\prime}$, from the ATG translation initiation codon (in bold) to $+21 \mathrm{nt}$. and reverse: 5'-CGAGGTACCTTA GCCGCCGGCAGCCGG- $3^{\prime}$, positions +294 to +312 corresponding to the stop codon (in bold). Both primers included the Kpn 1 restriction site (underlined). The reaction products were separated on $0.8 \%$ agarose electrophoretic gels.
For real-time quantitative RT-PCR studies, $\mathrm{T}_{1}$ transformed and control leaves of maize were collected and frozen into liquid $\mathrm{N}_{2}$ and stored at $-80^{\circ} \mathrm{C}$ until used for RNA extraction. Total RNA was extracted by the phenol/ chloroform method, followed by precipitation with $8 \mathrm{M}$ $\mathrm{LiCl}$ (Oñate-Sanchez and Vicente-Carbajosa 2008). cDNAs were synthesized from $2 \mu \mathrm{g}$ of RNA using the High-capacity cDNA reverse transcription kit (Applied Biosystems) following manufacturer's instructions. qRT-PCR analyses were performed for duplicated samples by means of a 7300 Real-Time PCR System (Applied Biosystems) using a SYBR Green detection system. Quantification was standardized to maize immunophilin mRNA levels using the primers described by Hueros et al. (1998). The primers used for PCR amplification were

- ZmFKBP-66 s -forward: 5'-GGGTGCTGTTGTTGAA GTCA-3';

- ZmFKBP-66as -reverse: 5'-GCAATAACTTCCTCAT CG-3'.

- MqrtIcy6 -forward: 5'-GCGGACGGCTCCGGCAAG AG-3';

- MqrtIcy6 -reverse: 5'-AAGGACGTGAGCTTGCGG GT- $3^{\prime}$ :

Inhibitory activity of protein extracts from maize plants expressing the barley cystatin

Total protein extracts from leaves were obtained from $T_{1}$ transformed and control maize plants. Leaves were ground and resuspended in $0.15 \mathrm{M} \mathrm{NaCl}$ sodium phosphate $\mathrm{pH} 6.0$, $2 \mathrm{mM}$ EDTA for $1 \mathrm{~h}$ at $4^{\circ} \mathrm{C}$ and treated as described in Alvarez-Alfageme et al. (2007). Inhibitory activity of plant protein extracts $(20 \mu \mathrm{g})$ was in vitro tested against $10 \mathrm{ng}$ of commercial papain (EC 3.4.22.2) from Sigma using Z-FRAMC as substrate. Similarly, inhibitory assays against $10 \mu \mathrm{g}$ of protein extracts prepared from T. urticae and $B$. chilensis were also performed using the substrates Z-RRAMC and Z-FR-AMC, following procedures described earlier.

Mite bioassays on maize plants expressing the barley cystatin

Mite bioassays were conducted on maize leaf fragments derived from $T_{1}$ plants of two transgenic lines ( $L 1$ and $\left.L 2\right)$ and from the control M37W. Leaf fragments of $3.0 \mathrm{~cm}$ long were placed onto wet cotton. surrounded by wet filter paper to avoid mite escapes and confined in petridishes. Dishes were maintained in controlled conditions at $25 \pm 2{ }^{\circ} \mathrm{C}, 70 \%$ relative humidity and a $16 \mathrm{~h} / 8 \mathrm{~h}$ day/night photoperiod. 
To study mite development, newborn larvae of T. urticae were placed on each leaf fragment and observed daily until mites became adults. Everyday the emerged adults were separated from the leaf fragments. Ten mites were placed on each leaf fragment and ten replicates (independent plants) of every line were done. To study the reproductive performance, two mite females and four mite males were placed on each test leaf fragment and the progeny produced scored after 7 days. The period was limited to 7 days to avoid the first generation progeny to reach the adult stage and start producing second-generation eggs. Twenty replicates (independent plants) of every line were used.

\section{Results}

Inhibitory properties of the barley cystatins against proteolytic activities of mites

The inhibitory capability of the whole cystatin members from barley was tested against the protease activity of two phytophagous mites. The 13 cystatins, expressed in E. coli cultures were purified to homogeneity by affinity chromatography to a $\mathrm{Ni}^{2+}$ column and finally eluted from it. Examples of some of them are shown by the stained bands detected after SDS-PAGE. In addition, the barley cysteineprotease cathepsin L-like EPB-2, target of cystatins is included in the sample as positive control (Fig. 1). Crude protein extracts from $T$. urticae and B. chilensis were prepared to perform in vitro inhibition assays with all recombinant barley cystatins. Specific substrates susceptible to be degraded by cathepsin L- and B-like were used.

M CPI-1 CPI-3 CPI-6 EPB-2 CPI-4 CPI-9 CPI-5

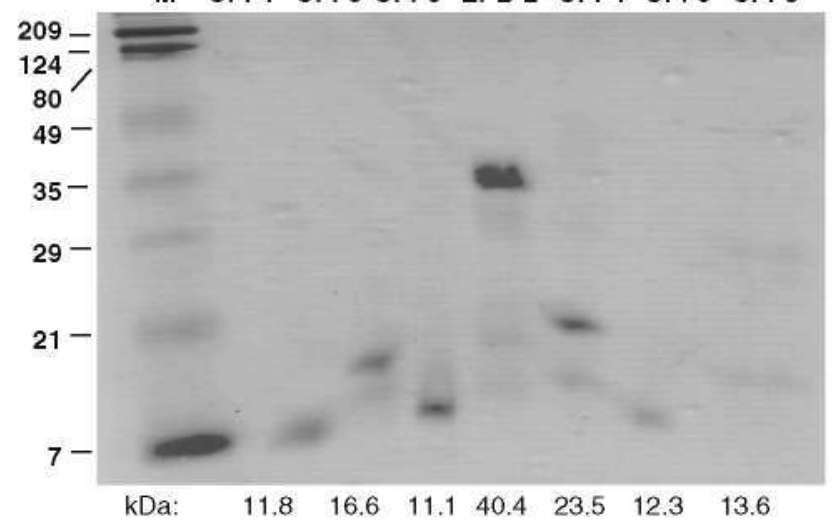

Fig. 1 Purification of the recombinant barley cystatins HvCPI-1, -3 , $-4,-5,-6$ and -9 proteins (CPI-1, CPI-3,CPI-4, CPI-5, CPI-6, CPI-9) and cathespin L-like- EPB-2 (EPB-2) from E. coli cultures by SDSPAGE. $2 \mu \mathrm{g}$ of each protein was loaded. The gel was stained with Comassie Brillant Blue $G$. Molecular markers $(M)$. Molecular size (kDa) of each cystatin is indicated under its corresponding gel lane
The inhibition profiles showed that T. urticae protease activities were more susceptible to be inhibited by barley cystatins than the $B$. chilensis enzymes (Table 1). Thus, cathepsin L-like activity detected in the crude extracts from T. urticae was inhibited by 11 barley cystatins, seven of these cystatins being also good inhibitors of cathepsin B-like activity. In contrast, in vitro assays performed with the crude protein extracts from $B$. chilensis showed that cathepsin L- and B-like activities were only inhibited by two and four different barley cystatins, respectively. However, among the 13 cystatin tested, the HvCPI-6 recombinant protein was the strongest inhibitor against proteolytic activities of both mites. It reduced about $90 \%$ their cathepsin L-like activity and diminished the cathepsin B-like activity by 90 and $47 \%$ in T. urticae and B. chilensis extracts, respectively. In contrast, no inhibition was detected when HvCPI-7 and HvCPI-12 proteins were used.

The inhibitory properties of the HvCPI- 6 were further analysed using mildly denaturing gelatine-PAGE. After electrophoretic mite protein separation and subsequent renaturation, active proteases hydrolysed gelatine showing clear lysis bands against the dark Coomassie blue stainedgelatin in the gel. As shown in Fig. 2, band profiles resulting from the two mites were very different. While only two mainly bands were resolved from $T$. urticae extracts, a multi-band pattern of protease activity appeared in B. chilensis sample. However, when mite extracts were pre-incubated with the HvCPI-6 recombinant cystatin purified form $E$. coli cultures, before loading the gel, most of the hydrolytic bands from the Chilean mite disappeared. In contrast, an almost undetectable inhibition of T. urticae bands was observed. Similar inhibitory effect was found after pre-treatment with the synthetic cysteine protease inhibitor E-64, although it showed a weaker inhibitory capability.

Characterization of $T$. urticae and B. chilensis protease activities

The proteolytic activity profile present in the protein extracts prepared from the two phytophagous mites was characterized. We analysed the optimum $\mathrm{pH}$, specific activity and effect of different protease inhibitors on the hydrolysis of specific substrates (Table 2). The two mites presented marked proteolytic activities of different mechanistic classes, having in common cathepsin B-like, cathepsin L-like and leucine aminopeptidase-like activities. These three types of proteolytic activities were detected throughout the range from $\mathrm{pH} 5.5$ to 7.5. Cathepsin B-like and L-like activities showed a maximum peak of activity at $\mathrm{pH} 5.5$ in $T$. urticae extracts while the optimum $\mathrm{pH}$ detected in B. chilensis for these two proteases was 7.0. In these two mite extracts both cathepsin activities were 
Table 1 In vitro inhibitory activity of the recombinant barley cystatins HvCPI-1 to HvCPI-13 against the two mite species, using the substrates Z-FR-AMC and Z-RR-AMC susceptible to be degraded by cathepsin L- and B-like, respectively

\begin{tabular}{|c|c|c|c|c|}
\hline \multirow[t]{3}{*}{ Cystatins } & \multicolumn{4}{|l|}{ Inhibition $^{\mathrm{a}}(\%)$} \\
\hline & \multicolumn{2}{|l|}{ T. urticae } & \multicolumn{2}{|l|}{ B. chilensis } \\
\hline & Z-FR-AMC substrate & Z-RR-AMC substrate & Z-FR-AMC substrate & Z-RR-AMC substrate \\
\hline HvCPI-1 & $61.6 \pm 4.3$ & $51.4 \pm 3.8$ & ne & ne \\
\hline HvCPI-2 & $51.3 \pm 4.1$ & $40.6 \pm 4.1$ & ne & ne \\
\hline HvCPI-3 & $55.8 \pm 4.5$ & $47.0 \pm 2.2$ & ne & ne \\
\hline HvCPI-4 & $55.2 \pm 2.6$ & $40.8 \pm 2.2$ & ne & ne \\
\hline HvCPI-5 & $90.6 \pm 1.0$ & $52.6 \pm 5.3$ & ne & $39.5 \pm 0.6$ \\
\hline HvCPI-6 & $90.3 \pm 1.0$ & $92.0 \pm 4.4$ & $86.3 \pm 0.7$ & $46.8 \pm 0.6$ \\
\hline HvCPI-7 & ne & ne & ne & ne \\
\hline HvCPI-8 & $64.5 \pm 0.3$ & $24.5 \pm 5.2$ & ne & $40.9 \pm 3.2$ \\
\hline HvCPI-9 & $61.8 \pm 3.1$ & ne & ne & ne \\
\hline HvCPI-10 & $24.2 \pm 3.2$ & ne & ne & $54.9 \pm 0.8$ \\
\hline HvCPI-11 & $33.0 \pm 0.8$ & ne & ne & ne \\
\hline HvCPI-12 & ne & ne & ne & ne \\
\hline HvCPI- 13 & $24.9 \pm 2.0$ & ne & $29.2 \pm 5.3$ & ne \\
\hline
\end{tabular}

No effect (ne) was considered for percentages of inhibition inferior to $20 \%$

${ }^{a}$ Values expressed in percentage are a mean $\pm \mathrm{SE}$ of triplicate measurements from a pool of extracts treated with the inhibitor $(0.4 \mu \mathrm{g}$ of cystatin) versus its corresponding control without it

\section{T. urticae}

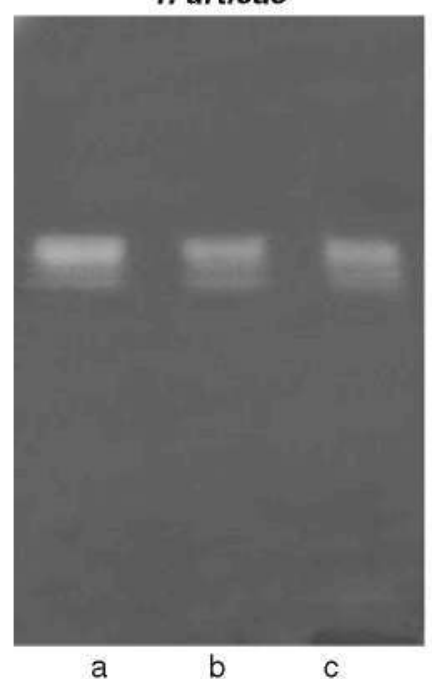

a

b

C

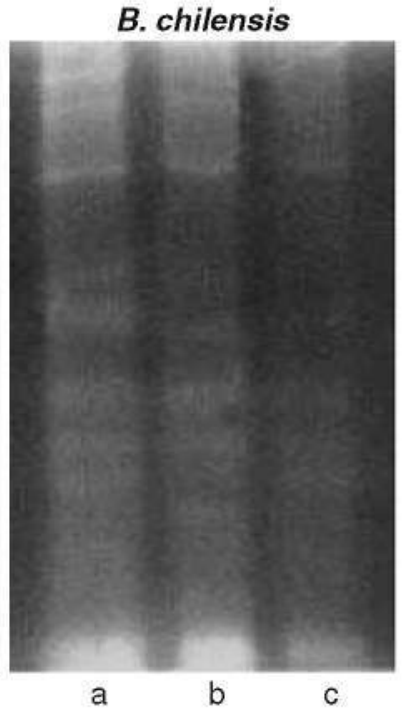

Fig. 2 Gelatin-containing SDS-PAGE gels of extracts from T. urticae and $B$. chilensis. Before electrophoresis, samples were treated with buffer alone (a), $100 \mu \mathrm{M}$ E-64 (b) or $70 \mu \mathrm{M}$ HvCPI-6 (c), for $15 \mathrm{~min}$ at $30^{\circ} \mathrm{C}$. Gels were incubated with $0.1 \mathrm{M}$ phosphate, $\mathrm{pH} 6.0$ and $10 \mathrm{mM}$ cysteine for $20 \mathrm{~h}$ at $30^{\circ} \mathrm{C}$

strongly inhibited by E-64, a cysteine-specific protease inhibitor. $\mathrm{CdCl}_{2}$ and soybean trypsin inhibitor (STI) presented a minor inhibition of these cysteine-protease activities. Besides, the leucine aminopeptidase-like activity showed the maximum proteolytic capability at $\mathrm{pH} 7.5$ and was inhibited by $\mathrm{CdCl}_{2}$ and pepstatin $\mathrm{A}$ in both mite species. In contrast, aspartic protease cathepsin D-like activity was specifically found in $T$. urticae protein extracts, while carboxypeptidases A- and B-like activities were only detected in extracts from $B$. chilensis. Cathepsin D-like optimal activity occurred at $\mathrm{pH} 3.0$ and it was specifically inhibited by pepstatin-A. The carboxypeptidases A- and B-like showed the highest activity at $\mathrm{pH} 8.0$ and 7.0, respectively, and were highly inhibited by $\mathrm{CdCl}_{2}$ and potato tuber carboxypeptidase inhibitor (PCPI). No hydrolysis of trypsin-, chymotrypsin- and elastase-like substrates was detected in the two mite extracts, even after $24 \mathrm{~h}$ of incubation.

Characterization of transgenic maize plants containing the barley cystatin

Transgenic maize lines were recovered in a phosphinotricine medium after culturing bombarded embryos with microparticles coated with the pUC-Icy6 (Fig. 3a) and pAHC25 constructs. Plants were screened by genomic PCR to identify primary cystatin transformants. In all ten lines analysed, the UbiIcy6 transgene presence was confirmed as is shown by amplifying a 321-bp diagnostic fragment (Fig. 3b). Lines L1 and L2 were selected for further experiments and the plants were crossed with wild-type M37W pollen to produce $T_{1}$ seeds. These two lines were representative of the Icy6-cystatin lines and were 
Table 2 Proteolytic activities from $T$. urticae and B. chilensis against specific substrates and effect of protease inhibitors at their optimum $\mathrm{pH}$

\begin{tabular}{|c|c|c|c|c|c|c|c|}
\hline \multirow[t]{2}{*}{ Protease } & \multirow[t]{2}{*}{ Optimum $\mathrm{pH}^{\mathrm{a}}$} & \multirow[t]{2}{*}{ Specific activity ${ }^{b}$} & \multicolumn{5}{|c|}{ Inhibition ${ }^{\circ}(\%)$} \\
\hline & & & Pep-A & E-64 & STI & PCPI & $\mathrm{CdCl}_{2}$ \\
\hline \multicolumn{8}{|c|}{ Tetranychus urticae } \\
\hline СТВ & 5.5 & $19.8 \pm 1.1$ & ne & $99 \pm 0.1$ & ne & ne & $23 \pm 3$ \\
\hline CTL & 5.5 & $22.2 \pm 2.1$ & ne & $88 \pm 2$ & ne & ne & ne \\
\hline CTD & 3.0 & $36.4 \pm 0.0$ & $68 \pm 8$ & ne & ne & ne & ne \\
\hline TRY & & nd & - & - & - & - & - \\
\hline $\mathrm{CHY}$ & & nd & - & - & - & - & - \\
\hline ELA & & nd & - & - & - & - & - \\
\hline LAP & 7.5 & $0.65 \pm 0.2$ & $47 \pm 2$ & ne & $25 \pm 4$ & ne & $87 \pm 2$ \\
\hline $\mathrm{CPA}$ & & nd & - & - & - & - & - \\
\hline CPB & & nd & - & - & - & - & - \\
\hline \multicolumn{8}{|c|}{ Brevipalpus chilensis } \\
\hline СТВ & 7.0 & $4.8 \pm 0.2$ & ne & $91 \pm 1$ & $26 \pm 1$ & ne & ne \\
\hline CTL & 7.0 & $15.3 \pm 0.5$ & ne & $89 \pm 0.2$ & ne & ne & ne \\
\hline CTD & & nd & - & - & - & - & - \\
\hline TRY & & nd & - & - & - & - & - \\
\hline $\mathrm{CHY}$ & & nd & - & - & - & - & - \\
\hline ELA & & nd & - & - & - & - & - \\
\hline LAP & 7.5 & $3.5 \pm 0.1$ & $39 \pm 2$ & ne & ne & ne & $59 \pm 4.7$ \\
\hline $\mathrm{CPA}$ & 8.0 & $36.2 \pm 0.1$ & ne & ne & ne & $82 \pm 1.4$ & $83 \pm 1.3$ \\
\hline $\mathrm{CPB}$ & 7.0 & $22.7 \pm 0.1$ & ne & ne & ne & $78 \pm 0.7$ & $75 \pm 1.0$ \\
\hline
\end{tabular}

$C T D$ cathepsin D, $C T B$ cathepsin B, $C T L$ cathepsin L, TRY trypsin, $C H Y$ chymoptrypsin, ELA elastase, $L A P$ leucine aminopeptidase, $C P A$ carboxypeptidase A and $C P B$ carboxypeptidase B, Pep-A pestatin A, E-64 L-trans-epoxysuccinyl-leucylamido-(4-guanidino)-butane), STI soybean trypsin inhibitor and $P C P I$ potato tuber caboxypeptidase inhibitor

" $\mathrm{pH}$ measurements were taken in the range $2.0-11.0$, with increments of $0.5 \mathrm{pH}$ units

b Specific activities as nmoles of substrate hydrolyzed/min/mg protein, except for proteolytic activity against haemoglobin as $\mathrm{mU} \Delta \mathrm{Abs}$ $280 \mathrm{~nm} / \mathrm{min} / \mathrm{mg}$ protein. Data are the mean $\pm \mathrm{SE}$ of triplicate measurements, nd No activity detected

c Values are mean $\pm S E$ of triplicate measurements treated with the inhibitor versus its corresponding controls without it. No effect (ne) was considered for inhibition under $20 \%$

characterised fully molecularly and biochemically through $\mathrm{T}_{1}$ generation.

The expression of the cystatin gene in leaves of ten $\mathbf{T}_{1}$ plants from each line (L1.1-L1.10 and L2.1-L2.10) and non-transformed control leaves (M37W) was analysed by real-time quantitative RT-PCR ( $q R T-P C R$ ) using specific primers. The content of cystatin mRNA was normalised to maize immunophilin transcript levels. Differences in the cystatin expression among the different transgenic plants within L1 and L2 lines were observed (Fig. 4a). No transcripts were found in the RNA isolated from non-transformed maize. Maize leaves were also used to prepare protein extracts and to analyse their in vitro inhibitory activity against the commercial papain. Results, quantified by the decrease amount of Z-FR-AMC-hydrolysed by the papain, were expressed of percentage of inhibitory enzyme activity (Fig. 4b). All transgenic plants showed inhibitory activity over the values obtained with protein extracts from the non-transformed control. Again, differences in the inhibitory capability among plants were observed. While plants $1.8,1.9 .2 .1,2.5$ and 2.7 inhibited almost completely the papain proteolytic activity, plants $1.3,1.4,1.6$ and 2.3 had very low or even no antipapain effect. The five plants within each line showing the stronger inhibitory properties against papain were selected to perform in vitro inhibitory assays against mite extracts.

To assess the mite sensitivity to transgenic maize extracts, Z-FR-AMC and Z-RR-AMC substrates susceptible to be hydrolysed by cathepsin L-and B-like activities, respectively, were used. As is shown in Fig. 4c. both protease activities were inhibited in the two mites. In general, T. urticae extracts were more susceptible to be inhibited by this barley cystatin than B. chilensis proteins. Interestingly, all transgenic plants derived from line $\mathrm{L} 2$ inhibited preferentially cathepsin B-like activity in $T$. urticae extracts (in the $65-100 \%$ range), whereas they reduced mainly cathepsin L-like activity in $B$. chilensis samples (about $50-80 \%$ ). In contrast. plants from line L1 did not show any 
(a)

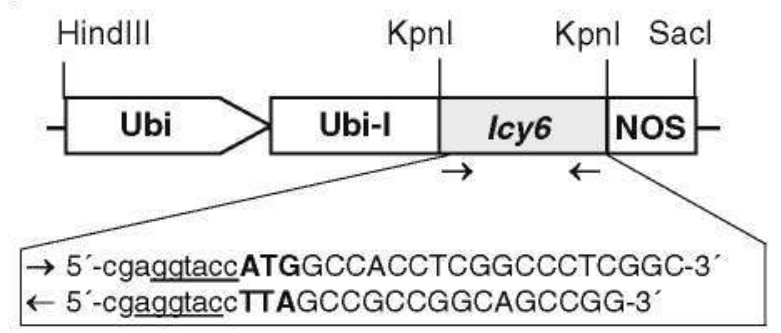

pUC-Icy6

(b)

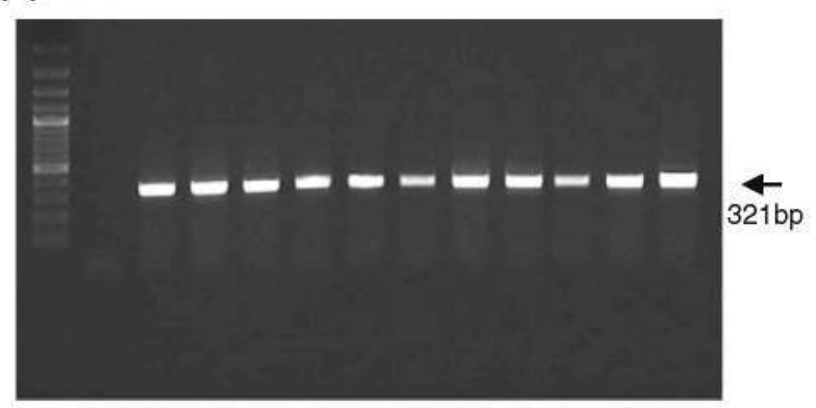

$\begin{array}{lllllllllllllllll}M & \text { W37 L1 } & \text { L2 L3 } & \text { L4 } & \text { L5 } & \text { L6 } & \text { L7 } & \text { L8 } & \text { L9 } & \text { L10 PI }\end{array}$

Fig. 3 Schematic representation of the pUC-Icy6 plasmid used for maize transformation and PCR analysis of the maize transgenic lines. a The PUC-Icy6 plasmid contains the barley cystatin gene (Icy6) flanked by the ubiquitine promoter (Ubi) plus its first intron (Ubi-I) and the nopaline synthase gene (NOS) $3^{\prime}$ terminator. Sites of restriction enzymes are included and specific primer pair (sense $\rightarrow$ and antisense $\leftarrow$ ) derived from the Icy6 gene used for PCR assays are indicated. The ATG translation initiation site and stop codon are in bold. Restriction Kpn I sites are underlined and added nucleotides to enhance restriction enzyme action are in lower letters. b PCR analysis of transgenic maize lines (L1-L10) and non-transformed control plant (M37W) using sense and antisense primers indicated in (a). Molecular size marker $(M)$ and the plasmid pUC-Icy6 $(P l)$ used as positive control are marked

preference for a specific cathepsin activity, with the exception of the plant 1.2 which seems to be a stronger inhibitor of catehpsin L-like in the two mite samples. No inhibitory effects were detected when protein extracts from MW37 control leaves were used.

\section{Effects of maize transgenic plants on T. urticae}

$\mathrm{T}_{1}$ plants of the transgenic lines $\mathrm{L} 1$ and $\mathrm{L} 2$ were used for the evaluation of $T$. urticae performance in maize leaves expressing the HvCPI-6 cystatin. Spider mite survival on the plants was not affected by the expression of the cystatin in any of the transgenic lines over the assayed period. In contrast, the development of immature stages fed on transgenic L1 and L2 plants to become adults suffered retardation of almost 1 day in comparison with those fed on non-transformed leaves. In addition, mite reproductive performance was significantly reduced after feeding on transgenic L2 plants, while it was not altered in those mites fed on L1 plants (Table 3).

Effects of maize transgenic plants on T. urticae proteolytic activity

To investigate the effect of the cystatin ingestion on the proteolytic pattern of $T$. urticae, protein extracts were prepared from the red spider mite reared on transgenic maize plants for 7 days. Both cathepsin L-like and cathepsin B-like activities were significantly reduced in mites fed on L2 maize plant expressing the barley cystatin, whereas only cathepsin L-like activity was inhibited in mites fed on the transgenic line L1, as is shown in Table 4.

\section{Discussion}

The general usefulness of PhyCys for pest control have been shown, particularly against phytophagous coleopteran species which rely mostly on cysteine protease activities for the digestion of dietary proteins (Fabrick et al. 2002; Lalitha et al. 2005; Alvarez-Alfageme et al. 2007). Moreover, many other studies have shown that PhyCys also affect the growth or survival of other insects, nematodes and slugs on artificial diets or delivered through transgenic plants (Walker et al. 1999; Lilley et al. 2004; Ribeiro et al. 2006; Konrad et al. 2009; Carrillo et al. 2010). In contrast, the anti-mite properties of cystatins have only been proven using the chestnut cystatin against house dust mite species (Pernas et al. 2000). In this context, the aim of the present study was to assess the putative acaricide effects of the whole barley gene cystatin family against two phytophagous mites, $T$. urticae and $B$. chilensis, with impact on agricultural crops and to select the best cystatin as trangene to study its in vivo impact.

We have previously characterized the in vitro inhibitory properties of the 13 members of the barley cystatin family purified as recombinant proteins against commercial and endogenous barley proteases (Abraham et al. 2006; Martinez et al. 2009). Here, these recombinant proteins were tested towards extracts prepared from $T$. urticae and B. chilensis. Our data showed that all barley cystatins, except HvCPI-7 and HvCPI-12, were able to in vitro inhibit cysteine-like proteases in at least one of two mite species tested. These results were in accordance with the specific inhibitory capability reported for these cystatins against different cathepsin-like proteases which also showed the lack of the inhibitory activity of HvCPI-7 and HvCPI-12 cystatins (Abraham et al. 2006; Martinez et al. 2009). Interestingly, cysteine-protease activities, particularly cathepsin L-like, from $T$. urticae were inhibited by most of the barley cystatins while only some cystatins inhibited 
Fig. 4 Molecular analysis of maize plants transformed with the Icy 6 barley gene encoding the HvCPI- 6 cystatin.

a Analysis of the expression of the barley cystatin in $10 \mathrm{~T}_{1}$ transgenic maize plants derived from two transgenic lines (L1 and L2) and non-transformed control (M37W) by real-time quantitative PCR. Values expressed as the relative mRNA contents of barley cystatin gene were standardized to the maize inmunophilin gene expression. b Inhibitory activity of protein extracts from $10 \mathrm{~T}_{1}$ transgenic maize plants derived form two transgenic lines (L1 and L2) and non-transformed control (M37W) against papain using Z-FR-AMC as substrate. Data are mean \pm SE of triplicate measurements of each sample. c Inhibitory activity of protein extracts from five $T_{1}$ transgenic maize plants derived from two transgenic lines (L1 and L2) and non-transformed control (W37M) against protein extracts from $T$. urticae and $B$. chilensis using Z-FR-AMC and Z-RR$\mathrm{AMC}$ as substrates for cathepsin L- (CTL) and cathepsin B-like proteases (CTB), respectively. Data are mean \pm SE of triplicate measurements of each sample
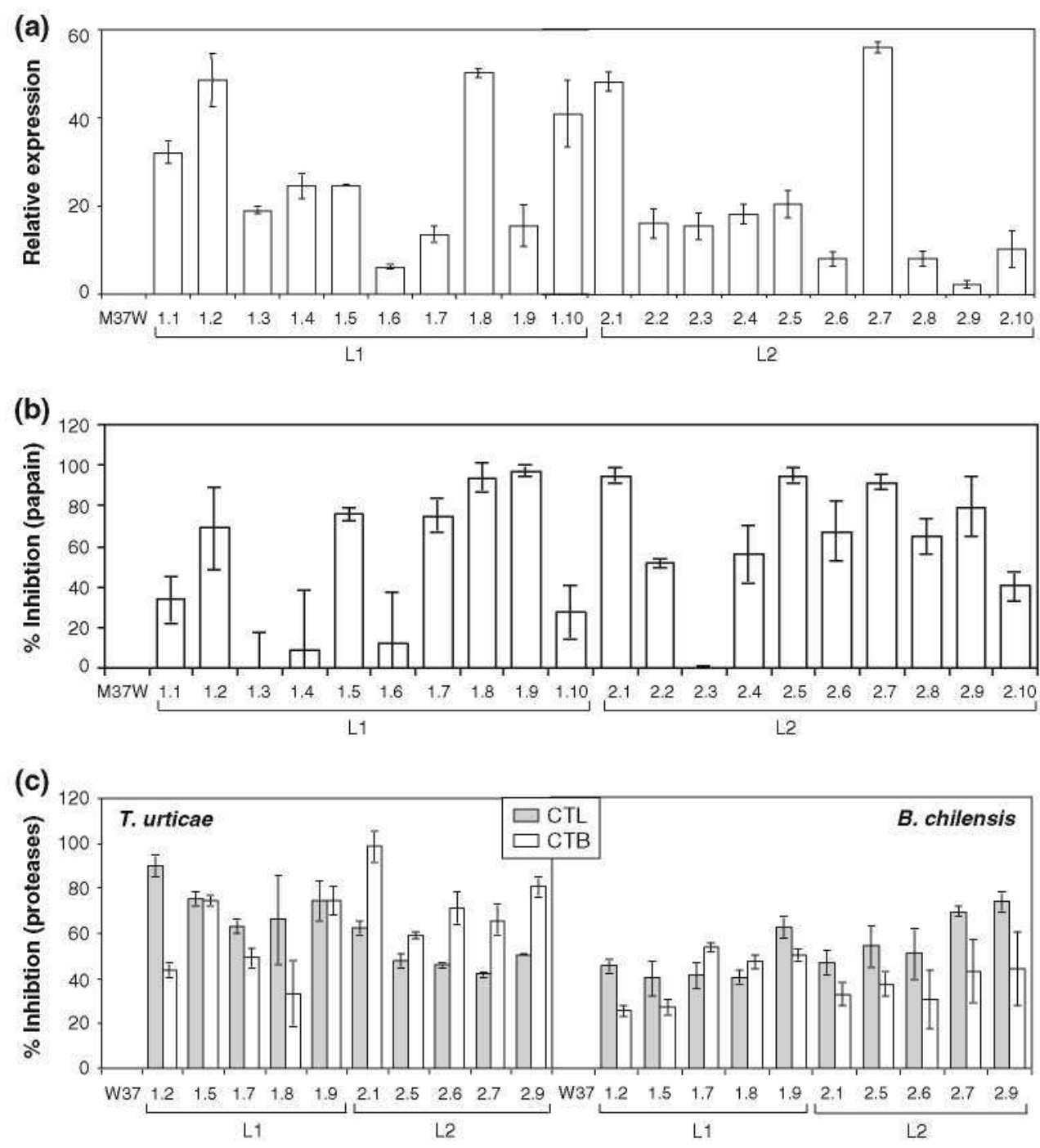

Table 3 Effects of the barley cystatin HvCPI-6 expressed on maize $\mathrm{T}_{1}$ plants on development and reproductive performance of $T$. urticae after feeding assay

\begin{tabular}{lrrrr}
\hline Maize & M37W & L1 & \multicolumn{1}{c}{ M37M } & \multicolumn{1}{c}{ L2 } \\
\hline Development $^{\mathrm{a}}$ (days) & $7.4 \pm 0.1$ & $8.2 \pm 0.1^{*}$ & $6.5 \pm 0.1$ & $7.5 \pm 0.1^{*}$ \\
Reproductive performance $^{\mathrm{b}}$ & $30.3 \pm 2.0$ & $25.8 \pm 2.1$ & $50.0 \pm 3.2$ & $41.7 \pm 3.0^{*}$ \\
\hline
\end{tabular}

* Significantly different from control (Dunnett two-tailed, $P<0.05$ )

a Number of days needed for the neonate larvae to become adult

Results are expressed as mean \pm SE using ten mites per maize leaf fragment and ten replicates of each transgenic line (L1 and L2) or its respective controls (M37W)

b Total progeny produced by two mite females and four mite males after 7 days feeding assay. Results are mean \pm SE of 20 replicates (leaves from independent plants) of each transgenic line (L1 and L2) or control plant (M37W). Two sets of experiments were conducted (10 replica per line) and the statistical analysis used a complete block design

efficiently B. chilensis protein extracts. Our findings indicated HvCPI-6 protein was the strongest inhibitor of cathepsin L- and B-like activities of both mites. However, the efficient inhibitory effects observed in vitro against T. urticae proteolytic activity differed from the lack of inhibition on the gelatinolytic bands detected on the zymogram. In contrast, an almost complete inhibition of the gelatinase bands from the $B$. chilensis extracts were detected after being preincubated with the HvCPI- 6 cystatin. These differences could be determined by the stability 
Table 4 Proteolytic activity profile $T$. urticae fed on transgenic maize $T_{1}$ plants (L1 and $L 2$ ) or on control plants (M37W)

\begin{tabular}{lcccc}
\hline $\begin{array}{l}\text { Proteolytic } \\
\text { activity }^{\mathrm{a}}\end{array}$ & \multicolumn{4}{l}{ Specific activity } \\
\cline { 2 - 5 } & M37W & \multicolumn{1}{c}{ L1 } & M37W & \multicolumn{1}{l}{ L2 } \\
\hline CTB & $12.4 \pm 0.4$ & $11.7 \pm 0.3$ & $15.2 \pm 0.3$ & $12.1 \pm 0.2^{*}$ \\
CTL & $13.1 \pm 0.7$ & $9.5 \pm 0.2^{*}$ & $16.7 \pm 0.7$ & $14.8 \pm 0.4^{*}$ \\
CTD & $36.6 \pm 1.6$ & $35.8 \pm 1.9$ & $34.4 \pm 2.0$ & $34.0 \pm 1.5$ \\
LAP & $0.8 \pm 0.0$ & $0.7 \pm 0.0$ & $0.6 \pm 0.2$ & $0.6 \pm 0.1$
\end{tabular}

Data are mean \pm SE of triplicate measurements from three biological samples

* Significantly different from control (Dunnett two-tailed, $P<0.05$ )

a Protease type abbreviations: as in Table 2

b Specific activities as in Table 2

of each cystatin/cysteine-protease complex (Michaud et al. 1996: Kiggundu et al. 2010), which in the case of T. urticae may favour dissociation during the electrophoretic process. According to Michaud et al. (1996), it is considered a weak complex stability when Ki values are higher than $10^{-8} \mathrm{M}$. In our hands the HvCPI- 6 Kis were in the $10^{-6}-10^{-7} \mathrm{M}$ range against commercial cathepsin $\mathrm{B}$ - and $\mathrm{H}$-like proteases, respectively, but its $\mathrm{Ki}$ values against most cathepsin L-like tested was $10^{-9} \mathrm{M}$ (Abraham et al. 2006: Martinez et al. 2009).

The characterization of protease activities of the two mites clarified the impact of cystatins and corroborated the presence of target enzymes in the spider mites. Michaud et al. (1996) had previously shown that protease activity in extracts from $T$. urticae was almost totally explained by cysteine-protease type in both in vitro assays and in zymograms. Likewise, proteolytic activities from $T$. urticae extracts were inhibited by E- 64 and pepstatin A indicating cysteine- and aspartic-protease activities, respectively, in this mite (Nisbet and Billingsley 2000). We have detected both cathepsin B- and L-like activities in $T$. urticae and $B$. chilensis whole extracts using specific substrates. These results are not surprising considering the prevalence and numerical importance of cysteine-protease coding sequences annotated in the genome of $T$. urticae (our unpublished results). In addition, $T$. urticae extracts presented cathepsin D-like activity whereas this activity was absent in the Chilean mite. Besides, leucine aminopeptidase-like activity was also present in both mites while carboxypeptidase A- and B-activities were only found in B. chilensis. Band proteolytic profiles of the two mites were also very different, with only two main bands in $T$. urticae, whereas $B$. chilensis yielded multiple-diffuse bands of protease activity. It has been suggested that the spectrum of digestive enzymes detected in mites reflect trophic specialization (Bowman 1984).
The expression of the HvCPI- 6 cystatin in transgenic maize allowed us to perform bioassays with $T$. urticae. We studied the potential interest of these transgenes to control spider mites as an alternative to Bt genes, which resulted unsuccessful against mite pests (Rovenska et al. 2005; Alvarez-Alfageme et al. 2008; Li and Romeis 2010). The transgenic maize lines generated ( $\mathrm{L} 1$ and L2) presented different transgene expression levels. This maybe due to the insertion of multiple copies of transgene in different chromosomal loci. Moreover, in many cases transgene expression levels are not always correlated to inhibition activity. This maybe due to the differences in protein levels. This is quite general characteristic described in transgenic plants. For these reasons. we selected the transgenic lines for performing bioassays based on their inhibitory capabilities. Interestingly, a significant development delay of $T$. urticae larvae to reach the adult stage in planta (transgenic lines L1 and L2) evidenced the anti-mite effects of the barley cystatin. However, the mite reproductive rate was only significantly affected after feeding on transgenic line L2. Probably, the higher inhibitory activity shown by maize L2 line against T. urticae cathepsin B-like, and the preference of L1 line to inhibit cathepsin L-like proteases could support the mite differential responses. The observed differences between control plants (M37W) were probably due to differences on the mite and/or plant physiology between the two sets of experiments conducted. As expected. the effect of the cystatin HvCPI- 6 retarding development time and reducing reproductive performance of $T$. urticae were correlated with a decrease of cathepsin L- and B-like protease activities after rearing on transgenic maize. It is important to have in mind that crude protein extracts were prepared from whole mites, and their cysteine-proteases can be involved in several physiological processes developed in different mite compartments. However, cathepsin D- and leucine aminopeptidase-like activities were not affected, suggesting that the spider mite did not develop a compensatory response to the inhibitory effect mediated by the barley cystatin. The overproduction of non-target proteases is usually found in other phytophagous arthropods as a response to host plants expressing distinct sets of defence proteins (Lara et al. 2000; Alvarez-Alfageme et al. 2007).

Taken together. all these results indicate that PhyCys could be a reliable source of plant resistance genes to be used as transgenes for conferring enhanced levels of resistant to phytophagous mites. As a proof of concept. transformation of maize with the barley cystatin HvCPI-6 impaired development and reproductive performance of T. urticae, highlighting the potential of this type of transgenic-derived plants for mite control. 
Acknowledgments We are grateful to Dr. Vicente Marco (Universidad de la Rioja, España) and Dr. Marina Gambardella (Pontificia Universidad Católica de Chile, Chile) for providing the colonies of $T$, urticae and the $B$. chilensis lyophilized samples, respectively. We thank Dr. Christou and Dr. Capell from the University of Lleida (Spain) for their support on the maize stable transformation. The financial support from the Spanish Ministerio de Ciencia e Innovación (project BFU2008-01166), the Agencia Española de Cooperación Internacional para el Desarrollo (Project A/023680/09) and the Spanish Ministerio de Medioambiente y Medio Rural y Marino is gratefully acknowledged.

\section{References}

Abraham Z, Martinez M, Carbonero P, Diaz I (2006) Structural and functional diversity within the cystatin gene family of Hordeum vulgare. J Exp Bot 57:4245-4255

Alvarez-Alfageme F, Martinez M, Pascual-Ruiz S, Castañera P, Diaz I. Ottego F (2007) Effects of potato plants expressing a barley cystatin on the predatory bug Podisus maculiventris via herbivorous prey feeding on the plant. Transgenic Res 16:1-13

Alvarez-Alfageme F, Ferry N, Castañera $P$, Ortego $F$, Gatehouse AMR (2008) Prey mediated effects of $\mathbf{B t}$ maize on fitness and digestive physiology of the red spider mite predator Stethorus punctillum Weise (Coleoptera: Coccinellidae). Transgenic Res $17: 943-954$

Bowman CE (1984) Comparative enzymology of economically important astigmatid mites. In: Griffiths DA, Bowman CE (eds) Acarology, Ellis Horwood, Chichester, UK, pp 993-1001

Bradford MM (1976) A rapid and sensitive method for the quantification of microgram quantities of protein utilizing the principle of protein-dye binding. Anal Biochem 72:248-254

Carbonelle S, Hance T, Migeon A, Baret P. Cros-Arteil S, Navajas M (2007) Microsatellite markers reveal spatial and genetic structure of Tetranychus urticae (Acari: Tetranychidae) populations along a latitudinal gradient in Europe. Exp Appl Acarol 41:225-241

Canillo L, Martinez M. Alvarez-Alfageme F, Castañera P. Smagghe G, Diaz I, Ortego F (2010) A barely cysteine-proteinase inhibitor reduces the performance of two aphid species in artificial diets and transgenic Arabidopsis plants. Transgenic Res doi: $10.1007 / \mathrm{s} 11248-010-9417-2$

Castagnoli M, Caccia R, Liguori M, Simoni S, Marinari S, Soressi GP (2003) Tomato transgenic lines and Tetranychus urticae: changes in plant suitability and susceptibility. Exp Appl Acarol $31: 177-189$

Christensen AH, Quail PH (1996) Ubiquitin promoter-based vectors for high-level expression of selectable and/or screenable marker genes in monocotyledoneous plants. Transgenic Res 5:213-218

Croft BA, Van de Baan HE (1988) Ecological and genetic factors: influencing evolution of pesticide resistance in Tetranychid and Phytoseiid mites. Exp Appl Acarol 4:277-300

Fabrick J, Behnke C, Czapla T, Bala K, Rao AG, Kramer KJ, Reeck GR (2002) Effects of a potato cysteine proteinase inhibitor on midgut proteolytic enzyme activity and growth of the southern corn rootworm. Diabrotica undecinpunctata howardi (Coleoptera: Chrysomelidae). Insect Biochem Mol Biol 32:405-415

Fuentealba L (2003) Control de la falsa arañita de la vid (Brevipalpus chilensis Baker) en vid vinifera bajo producción orgánica. Master Project. Pontificia Universidad Católica de Chile

Girard C. Rivard D. Kiggundu A. Kurnet K. Gleddie SC, Cloutier C, Michaud D (2007) A multicomponent, elicitor-inducible cystatin complex in tomato, Solamum tycopersicum. New Phytol $173: 841-851$
Gutierrez-Campos R, Torres-Acosta J, Saucedo-Arias LJ, GomezLim MA (1999) The use of cysteine proteinase inhibitors to engineer resistance against potyviruses in transgenic tobacco plants. Nat Biotechnol 17:1223-1226

Hamilton KA, Nisbet AJ, Lehane MJ, Taylor MA, Billingsley PF (2003) A physiological and biochemical model for digestion in the ectoparasitic mite, Psoroptes ovis (Acari: Psoroptidae). Int J Parasitol 33:773-785

Hueros G, Rahfeld J, Salamini F, Thompson R (1998) A maize FK506-sensitive inmunophilin, $m z F K B P-66$, is a peptylproline cis-trans-isomerase that interacts with calmodulin and a $36 \mathrm{kDa}$ cytoplasmic protein. Planta 205:121-131

Jeppson LR, Keifer HH, Baker EW (1975) Mites injurious to economic plants. University of California Press, USA

Kiggundu A. Muchweizi J, Van der Vyer C, Viljoen A, Varster J. Schluter U, Kunert K. Michaud D (2010) Deletereous effects of plant cystatins against the banana weevil Cosmopolites sordidus. Arch Insect Biochem Phsyiol 73:87-105

Konrad R, Connor M, Ferry N, Gatehouse AMR, Babendreier D (2009) Impact of transgenic oilseed rape expressing oryzacystatin-1 (OC-1) and of insecticidal proteins on longevity and digestive enzymes of the solitary bee Osmia bicomis. J Insect Physiol 55:305-313

Lalitha S, Shade RE, Murdock LL. Bressan RA. Hasegawa PM. Nielsen SS (2005) Effectiveness of recombinant soybean cysteine proteinase inhibitors against selected crop pests. Comp Biochem Physiol 140:227-235

Lantz MS, Ciborowski P (1994) Zymographic techniques for detection and characterization of microbial proteases. Meth Enzymol 235:563-594

Lara P. Ortego F, Gonzalez-Hidalgo E. Castañera P. Carbonero P. Diaz I (2000) Adaptation of Spodoptera exigua (Lepidoptera: Noctuidae) to barley trypsin inhibitor BTI-CMe expressed in transgenic tobacco. Transgenic Res 9:169-178

Li Y, Romeis J (2010) Bt maize expressing Cry3Bb1 does not harm the spider mite, Tetranychus urticae, or its ladybird beetle predator, Stethons punctillum. Biol Control 56:157-164

Lilley CJ, Urwin PE, Johnston KA, Atkinson HJ (2004) Preferential expression of a plant cystatin at nematode feeding sites confers resistance to Meloidogme incognita and Globodera pallida. Plant Biotech J 2:3-12

Margis R, Reis EM, Villeret V (1998) Structural and phylogenetic relationships among plant and animal cystatios. Arch Biochem Biophys 359:24-30

Martinez M. Diaz I (2008) The origin and evolution of plant cystatins and their target cysteine proteinases indicate a complex functional relationship. BMC Evol Biol 8:198

Martinez M, Lopez-Solanilla E, Rodriguez-Palenzuela P, Carbonero P, Diaz I (2003) Inhibition of plant-pathogenic fungi by the barley cystatin Hv-CPI (gene $/ c y$ ) is not associated with its cysteine-proteinase inhibitory properties. Mol Plant-Microbe Interact 16:876-883

Martinez M. Diaz-Mendoza M. Carrillo L. Diaz I (2007) Carboxy terminal extended phytocystatins are bifunctional inhibitors of papain and legumain cysteine proteinases. FEBS Lett 581:2914-2918

Martinez M, Cambra I, Carrillo L, Diaz-Mendoza M, Diaz I (2009) Characterization of the entire cystatin gene family in barley and their target cathepsin L-like cysteine-proteases, partners in the hordein mobilization during seed germination. Plant Physiol 151:1531-1545

McCafferty HRK, Moore PH, Zhu Y (2006) Improved Carica papaya tolerance to carmine spider mite by the expression of $M$ anduca sexta chitinase transgene. Transgenic Res 15:337-347

McCafferty HRK, Moore PH. Zhu Y (2008) Papaya transformed with the Galanthus mivalis GNA gene produces a biologically active lectin with spider mite control activity. Plant Sci 175:385-393 
Michaud D, Cantin L, Raworth DA, Varin TC (1996) Assessing the stability of cystatin/cysteine proteinase complexes using mildydenaturing gelatine-polyacrylamide gel electrophoresis. Electrophoresis 17:74-79

Nisbet AJ, Billingsley PF (2000) A comparative survey of the hydrolytic enzymes of ectoparasitic and free-living mites. Int $\mathbf{J}$ Parasitol 30:19-27

Nissen MS, Kumar GNM, Youn B, Knowles DB, Lam KS, Ballinger WI, Knowles NR, Kang CH (2009) Characterization of Solanum tuberosum multicystatin and its structural comparison with other cystatins. Plant Cell 2:861-875

Novillo C、 Castañera P, Ortego F (1997) Characterization and distribution of chymotrypsin-like and other digestive proteases in Colorado potato beetle larvae. Arch Insect Biochem Physiol 36:181-201

Obrist LB, Klein H. Dutton A, Bigler F (2006) Assessing the effects of $\mathrm{Bt}$ maize of the predatory mite Neoseinhus cucumeris. Exp Appl Acarol 38:125-139

Oerke EC (2006) Crop losses to pests. J Agric Sci 144:31-43

Onate-Sanchez L, Vicente-Carbajosa J (2008) DNA-free RNA isolation protocols for Arabidopsis thatiana, including seeds and siliques. BMC Res Notes 1:93

Ontego F. Novillo C. Castañera P (1996) Characterization and distribution of digestive proteases of the stalk corn borer, Sesamia nonagrioides Lef (Lepidoptera: Noctuidae). Arch Insect Biochem Physiol 33:163-180

Pernas M. Sanchez-Monge R. Gomez L、 Salcedo G (1998) A chestnut seed cystatin differentially effective against cysteine proteinase from closely related pests. Plant Mol Biol 38:1235-1242

Pernas M, Sanchez-Monge R, Sanchez-Ramos I, Lombardero M, Arteaga C, Castañera P. Salcedo G (2000) Der p1 and Der f1, the highly related and major allergens from house mites, are differentially affected by a plant cystatin. Clin Exp Allergy 30:972-978

Ramessar K, Rademacher T, Sack M, Stadlmann J, Platis D, Steigler G, Labrou N, Altmann F, Ma J, Stoger E, Capell T, Christou P (2008) Cost-effective production of a vaginal protein microbicide to prevent HIV transmission. Proc Natl Acad Sci USA 105:3727-3732

Ribeiro APO, Pereira EJC, Galvan TL, Picanzo MC, Picoli EAT, da Silva DJH, Fari MG. Otoni WC (2006) Effect of eggplant transformed with oryzacystatio gene on Myzus persicae and Macrosiphum euphorbiae. J Appl Entomol 130:84-90

Rovenska GZ, Zemek R, Schmidt EU, Hilbeck A (2005) Altered host plant reference of Tetranychus unticae and prey preference of its predator Phytoseiulus persimilis (Acari: Tetranychidae, Phytoseiidae) on transgenic Cry3Bb-eggplants. BioControl 33:293-300

Salvesen G, Nagase H (1989) Inhibition of proteolytic enzymes. In Beynon R, Bond JS (eds): Proteolytic Enzymes: A Practical Approach. Oxford: IRL Press at Oxford University Press. pp 83-104

Stubbs MT, Laber B, Bode W, Huber R, Jerala R, Lenarcic B, Turk V (1990) The refined 2.4 A X-ray crystal structure of recombinant human stefin $B$ in complex with the cysteine proteinase papain: a novel type of proteinase inhibitor interaction. EMBO J 9:1939-1947

Taylor B, Powell A (1982) Isolation of plant DNA and RNA. Focus $4: 4-6$

Walker AJ, Urwin PE, Atkinson HJ, Glen DM, Shewry PR (1999) Transgenic Arabidopsis leaf tissue expressing a moditied oryzacystatin shows resistance to the field slug Deroceras reticulatum (Muller.) Transgenic Res 8:95-103 